\title{
Uterine oxytocin responsiveness and maternal recognition of pregnancy in the mare
}

\author{
T.A.E. Stout and W.R. Allen \\ University of Cambridge, Department of Clinical Veterinary Medicine, Cambridge, U.K.
}

\begin{abstract}
Summary
Establishment of pregnancy in the mare, as with the other large domestic animal species, depends on the conceptus-orchestrated suppression of endometrial prostaglandin $F_{2 x x}\left(P F_{2 \alpha}\right)$ secretion during days 11-16 after ovulation, the period when cyclical luteolysis would otherwise occur. It is frustrating that, in the mare, the conceptus signal(s) responsible for prolonging the lifespan of the corpus luteum (CL) has not been identified. Nor is it understood how suppression of $\mathrm{PGF}_{2 \alpha}$ release is achieved. However, recent studies have suggested that oxytocin plays an important role in driving the endometrial releases of $\mathrm{PGF}_{2 \alpha}$ that cause luteolysis in the cycling mare and, with this in mind, the current paper reviews the evidence in favour of the hypothesis that luteostasis during early pregnancy depends on an inhibition of endometrial oxytocin responsiveness, as it does in ruminants. In addition, we examine the extent to which mechanisms other than the hypothesised inhibition of endometrial oxytocin receptors are necessary if the conceptus is to realise its goal of extending the lifespan of the primary $\mathrm{CL}$ beyond the time of endometrial cup formation and thus secretion of equine Chorionic Gonadotrophin (eCG).
\end{abstract}

Keywords: $\quad$ mare, pregnancy, oxytocin, uterus, prostaglandin $F_{2 \alpha}$

\begin{abstract}
Uterine Ansprechbarkeit auf Oxytocin und maternale Erkennung der Gravidität bei der Stute
Wie bei den anderen großen Haustierarten hängt die Etablierung der Trächtigkeit bei der Stute ab von der durch den Konzeptus ausgelösten Unterdrückung der endometrialen $\mathrm{PGF}_{2 \alpha}$-Sekretion während des 11.-16. Tages post ovulationem, also der Zeit, in der sonst die zyklische Luteolyse eingesetzt hätte. Bedauerlicherweise ist das Signal des Konzeptus, das für das Persistieren des Corpus luteum verantwortlich ist, beim Pferd nicht identifiziert. Auch ist nicht klar, wie die Suppression der PGF ${ }_{2 \alpha}$-Freisetzung erreicht wird. Dagegen wurde in neuesten Arbeiten vermutet, daß das Oxytocin eine wichtige Rolle in der Regulation der endometrialen $\mathrm{PGF}_{2 \alpha}$-Abgabe während der zyklischen Luteolyse spielt. Mit diesem Hintergrund wird in diesem Artikel versucht, den Nachweis der Hypothese zu führen, daß die Luteostase in der Frühträchtigkeit beim Pferd, wie beim Rind, von der Hemmung der endometrialen Oxytocin-Ansprechbarkeit abhängt. Zusätzlich wird untersucht, in welchem Ausmaß andere Mechanismen als die hypothetisierte Inhibition der endometrialen Oxytocinrezeptoren notwendig sind, falls der Konzeptus sein Ziel erreicht, die Persistenz des primären Corpus luteum über die Zeit der Formation der endometrial cups und damit der Sekretion von equinem Choriongonadotropin, eCG, zu initiieren.
\end{abstract}

Schlüsselwörter: Stute, Trächtigkeit, Oxytocin, Uterus, PGF $_{2 \alpha}$

\section{Introduction}

Short (1969) coined the term „maternal recognition of pregnancy" to describe the process by which the dam determines biochemically that a conceptus is present in her uterus and makes the appropriate physiological changes to ensure that a suitable environment is established for the future growth and development of that conceptus. In polyoestrous species, the term has come to refer specifically to the conceptus-initiated events which result in prolongation of the lifespan of the CL, since progesterone secreted by this structure stimulates many of the changes which ensure nutrients for, and otherwise protect, the growing embryo. In the mare, the antiluteolytic effect of the conceptus appears to be manifested as an absolute reduction in uterine PGF ${ }_{2 \alpha}$ synthesis and/or release during the luteolytic period (Sharp et al., 1988) and the remarkably long period of intrauterine mobility of the conceptus until around day 16-17 after ovulation, is essential if the conceptus is to deliver enough of its anti-luteolytic message to a sufficient proportion of the total area of endometrium to inhibit $\mathrm{PGF}_{2 \alpha}$ release from the latter. If the mobility of the conceptus is restricted, luteolysis will occur and pregnancy loss will follow (McDowell et al., 1985).

\section{Maternal recognition of pregnancy in ruminants}

As in the mare, luteolysis in the domestic ruminants is effected by pulses of $\mathrm{PGF}_{2 \alpha}$ released by the endometrium. However, it is now well established in these species that oxytocin secreted by the CL plays a pivotal role in the luteolytic process because it stimulates the endometrium to

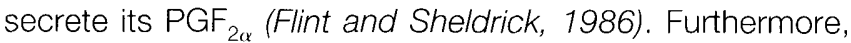
the critical step in the initiation of this luteolytic pathway is a dramatic upregulation of oxytocin receptors (OTRs) within the endometrium and the resulting development of 'oxytocin sensitivity' (Wathes et al., 1996). Once this has occurred, and because $\mathrm{PGF}_{2 \alpha}$, in turn, stimulates oxytocin secretion, luteal oxytocin and endometrial $\mathrm{PGF}_{2 \alpha}$ engage in a positive feedback loop which generates the large pulses of $\mathrm{PGF}_{2 \alpha}$ needed to effect luteolysis (Silvia et al., 1991).

The discovery that oxytocin and its endometrial receptor are central to luteolysis has helped considerably to explain how a developing ruminant conceptus prevents the destruction of its mother's CL. It secretes directly onto the endometrium an unique antiluteolytic protein, interferon tau (IFN- $\tau$ : Bazer, 1992), which acts primarily to prevent the cyclical upregulation of OTRs and, in so doing, disarms the oxytocin-PGF $2 \alpha$ positive feedback loop (McCracken et al., 1984). This, in 
turn, disrupts the pattern of $\mathrm{PGF}_{2 \alpha}$ secretion and prevents the generation of the large pulses of hormone required to effect luteal destruction (Payne and Lamming, 1994).

\section{The role of oxytocin in cyclical luteolysis in the mare}

Initially, it was thought that control of $\mathrm{PGF}_{2 \alpha}$ release during luteolysis in the mare differed fundamentally from the mechanisms employed by ruminants and early authors suggested that oxytocin was not involved at all in the process (Neely et al., 1979). However, Betteridge et al. (1985) discovered that administration of oxytocin to mares in late dioestrus provoked an immediate increase in peripheral plasma concentrations of 13, 14-dihydro 15-keto $\mathrm{PGF}_{2 \alpha}$ (PGFM), the major circulating metabolite of $\mathrm{PGF}_{2 \alpha}$, and Goff et al. (1987) went on to demonstrate that a measurable $\mathrm{PGF}_{2 \alpha}$-release response to oxytocin challenge first appears on day 11 after ovulation in the cycling mare and the response rises to peak during days 14-16, coincident with functional luteolysis. More recently, Sharp et al. (1997) and Starbuck et al. (1998) have both reported that this late dioestrous increase in endometrial oxytocin sensitivity correlates with a simultaneous increase in endometrial oxytocin binding capacity, thereby supporting the contention that the development and function of oxytocin receptors in the endometrium of the mare change in a manner consistent with oxytocin having an important role in luteolysis. Additionally, a number of recent studies have indicated that, in the mare, the endometrium itself is the primary source of the oxytocin involved in cyclical luteolysis (Behrendt et al., 1997: Watson et al., 1997: Stout et al., 1999).

\section{Oxytocin receptors and maternal recognition of preg- nancy in the mare}

If it is accepted that the development of uterine sensitivity to oxytocin is the critical step in the onset of luteolysis in the non-pregnant mare, it becomes easier to conceive how the conceptus might act to suppress PGF $_{2 \alpha}$ secretion during the period of maternal recognition of pregnancy. Between days 11 and 16 after ovulation, pregnant mares do not develop the ability to secrete $\mathrm{PGF}_{2 \alpha}$ in response to oxytocin challenge in the way that non-pregnant mares do so dramatically (Goff et al., 1987; Starbuck et al., 1998). Therefore, it is likely that the antiluteolytic signal(s) secreted by the equine blastocyst acts either to prevent the development of oxytocin sensitivity in the endometrium or it uncouples the interaction between the oxytocin-OTR complex and the prostaglandin synthesis pathway. In this respect, OTRs are reduced, both in number and in their affinity for oxytocin, during days 12-14 of pregnancy (Sharp et al., 1997; Starbuck et al., 1998). However, the level of suppression is not as complete as that seen in ruminants during the equivalent period and it is therefore unlikely that inhibition of OTR activity alone accounts for the almost total suppression of $\mathrm{PGF}_{2 \alpha}$ release that occurs. Hence, it is necessary to specu- late that some other mechanism(s), which is probably beyond oxytocin receptor suppression, must complete the inhibition of $\mathrm{PGF}_{2 \alpha}$ release during early pregnancy.

\section{Other 'control points' in equine pregnancy recognition}

Given the importance of the dam's recognition of her pregnancy state to embryonic survival, it would not be surprising if more than one pathway was employed to ensure $C L$ survival. Indeed, cattle embryos appear to use more than one mechanism to inhibit uterine $\mathrm{PGF}_{2 \alpha}$ release and pregnant bovine endometrium secretes up to $50 \%$ less $\mathrm{PGF}_{2 \alpha}$ than cyclical endometrium when incubated in vitro due to the existence in the tissue of an intrinsic endometrial prostaglandin synthesis inhibitor (EPSI; Thatcher et al, 1995), the expression and activity of which is enhanced by the IFN- $\tau$ secreted by the elongating bovine trophoblast. However, although Franklin et al. (1989) reported significantly lower levels of $\mathrm{PGF}_{2 \alpha}$ secretion in vitro by endometrium recovered from pregnant mares versus cycling mares, other studies have not supported this finding (Sharp et al., 1988; Stout, 1998). Thus, if the antiluteolytic actions of the equine conceptus are not sustained constitutively in endometrium removed from a pregnant mare, it seems most unlikely that an equine analogous EPSI exists. If it does, its action must be extremely short-lived.

Finally, while recent experiments have demonstrated that the uterus of the mare is a major potential source of oxytocin during cyclical luteolysis, they may have also unearthed an additional contribution to a reduced oxytocin- PGF $_{2 \alpha}$ drive during pregnancy. Namely, Behrendt et al. (1997) noted that the expression of mRNA for oxytocin in the endometrium of the mare is lower during early pregnancy than at an equivalent stage of the oestrous cycle and Stout (1998) found a similar reduction in uterine lumenal oxytocin concentrations during days 14-18 of gestation. On the other hand, Watson et al. (1997) reported an increase in the concentrations of oxytocin peptide within endometrial epithelial cells during early pregnancy, compared to late dioestrus, and therefore it appears that both oxytocin production and release are reduced during early pregnancy, thereby reducing the hormonal drive to luteolysis.

\section{Uterine lumenal concentrations of $\mathrm{PGF}_{2 \alpha}$}

Recently, we measured concentrations of $\mathrm{PGF}_{2 \alpha}$ within the uterine lumen of day 18-30 pregnant mares and found these to be of the same order as the levels recorded in the uteri of mares undergoing cyclical luteolysis (Stout and Allen, 1998). This observation complimented the finding by Starbuck et al. (1997) that, although the ability of the uterus to respond to oxytocin challenge is inhibited between days 10 and 14 of gestation, its responsiveness begins to recover by day 18. Taken together, these findings seem to suggest that the antiluteolytic strategy of the equine blastocyst is not to induce a total abolition of the luteolytic mechanism but, 
rather, a delay in the development of oxytocin sensitivity so as to protect the CL until a stage of pregnancy when a significant oxytocin challenge is unlikely to occur. From a practical standpoint, this leaves the day 18-30 conceptus in a remarkably precarious position because, at least in theory, luteolysis could be initiated by any stimulus that caused oxytocin release, including manipulation of the uterus (Sharp et al., 1997), such as might occur during manual palpation per rectum to diagnose pregnancy or vigorous reduction of twins to a singleton pregnancy. This potential for a re-establishment of the luteolytic mechanism after day 18 to endanger the survival of the pregnancy was demonstrated unintentionally by Allen (1975) when he discovered that 3 injections of a normal dose of human Chorionic Gonadotrophin (hCG) given to mares on alternate days between 18 and 33 days of gestation resulted in pregnancy failure and a return to oestrus. Subsequently, Urwin (1985) demonstrated that this resulted from PGF $2 x$-induced luteolysis while Daels and colleagues (pers. comm.) have suggested that small quantities of endotoxins co-purified with hCG in the extraction process are the most likely cause of the untoward $\mathrm{PGF}_{2 \alpha}$ release.

\section{Conclusions}

The conceptus factor(s) that inhibit endometrial release of $\mathrm{PGF}_{2 \alpha}$ during early pregnancy in the mare continues to elude identificaion. There remains considerable merit in determining the nature of this signal, and its mechanism of action, since such information might well enable the development of methods to predict and/or limit early pregnancy losses. Establishing a definite role for oxytocin in the control of cyclical luteolysis in the mare has helped to identify a number of potential "control-points" at which the conceptus might exert its luteostatic action. In addition, it is anticipated that further investigations into the expression and regulation of the endometrial receptor for oxytocin may advance considerably our understanding of how equine luteolysis is controlled, how the spherical, unattached conceptus interferes with this process and what happens when one or other of the mechanisms fails.

The likelihood that the luteolytic pathway is re-activated between days 18-30 after ovulation is of both scientific interest and considerable practical importance as to how best to manage pregnant mares to minimise the potential for untoward diagnostic or therapeutic manipulations disturbing the status quo during the „risk period" of equine pregnancy.

\section{Literature}

Allen WE (1975): Pregnancy failure induced by human Chorionic Gonadotrophin in pony mares. Vet. Rec. 96, 88-90.

Bazer FW (1992): Mediators of maternal recognition of pregnancy in mammals. Proc. Soc. exp. Biol. Med. 199, 373-384.

Behrendt CY, Adams MH, Daniel KS and MCDowell KJ (1997): Oxytocin expression by equine endometrium. Biol. Reprod. 56 Suppl. 1, 134.

Betteridge KJ, Renard A and Goff AK (1985): Uterine prostaglandin release relative to embryo collection, transfer procedures and maintenance of the corpus luteum. Equine vet. J. Suppl. 3, 25-33.

Flint APF and Sheldrick EL (1986): Ovarian oxytocin and the maternal recognition of pregnancy. J. Reprod. Fert. 76, 831-839.

Franklin KJ, Gross TS, Dubois DH and Sharp DC (1989): In vitro prostaglandin secretion from lumenal and myometrial sides of endometrium from cyclic and pregnant mares at day 14 post partum. Biol. Reprod. 49, Suppl. 1, Abstract 199.

Goff AK, Pontbriand $D$ and Sirois J (1987): Oxytocin stimulation of plasma 15-keto-13,14-dihydro prostaglandin $F_{2 \alpha}$ during the oestrous cycle and early pregnancy in the mare. J. Reprod. Fert. Suppl. 35, 253-260.

McCracken JA, Schramm W and Okulicz WC (1984): Hormone receptor control of pulsatile secretion of $\mathrm{PGF}_{2 \alpha}$ from the ovine uterus during luteolysis and its abrogation in early pregnancy. An. Reprod. Sci. 7, 31-55.

McDowell KJ, Sharp DC, Peck LS, and Cheves LL (1985): Effect of restricted conceptus mobility on maternal recognition of pregnancy in mares. Equine vet. J. Suppl. 3, 23-24.

Neely DP, Stabenfeldt GH and Sauter CL (1979): The effect of exogenous oxytocin on luteal function in mares. J. Reprod. Fert. 55, 303-308.

Payne JH and Lamming GE (1994): The direct influence of the embryo on uterine $\mathrm{PGF}_{2 \alpha}$ and $\mathrm{PGE}_{2}$ production in sheep. J. Reprod. Fert. 101, 737-741.

Sharp DC, MCDowell KJ and Weithenauer J (1988): Establishment of pregnancy and embryo loss in the mare. Proc. 11th Int. Cong. Anim. Reprod. and Al. pp 347-353.

Sharp DC, Thatcher M-J, Salute ME and Fuchs AR (1997): Relationship between endometrial oxytocin receptors and oxytocin induced prostaglandin $\mathrm{F}_{2 \alpha}$ release during the oestrous cycle and early pregnancy in pony mares. J. Reprod. Fert. 109, 137-144.

Short RV (1969): Implantation and the maternal recognition of pregnancy. In: Ciba Foundation Symposium on Foetal Autonomy. Eds. GEW Wolstenholme and Maeve O'Connor. J and A Churchill Ltd., London, UK. pp 2-26.

Silvia WJ, Lewis GS, McCracken JA, Thatcher WW and Wilson $L$ (1991): Hormonal regulation of uterine secretion of PGF $_{2 \alpha}$ during luteolysis in ruminants. Biol. Reprod. 45, 655-663.

Starbuck GR, Stout TAE, Lamming GE, Allen WR and Flint APF (1998): Endometrial oxytocin receptor and uterine prostaglandin secretion in mares during the oestrous cycle and early pregnancy. J. Reprod. Fert. 113, 173-179.

Stout TAE (1998): Maternal recognition of pregnancy in the mare. PhD thesis, University of Cambridge.

Stout TAE and Allen WR (1998): Uterine lumenal prostaglandin concentrations during late dioestrus and early pregancy in the mare. J. Reprod. Fert. Abstract series 22, 45.

Stout TAE, Lamming GE and Allen WR (1999): The uterus as a source of oxytocin in the cycling mare. J. Reprod. Fert. Suppl. (In press).

Thatcher WW, Meyer MD and Danet-Desnoyers G (1995): Maternal recognition of pregnancy. J. Reprod. Fert. Suppl. 49, 15-28.

Urwin Valerie (1985): Gonadotrophic control of ovarian function in pregnant equids. PhD Thesis, University of Cambridge.

Wathes DC, Mann GE, Payne JH, Riley PR, Stevenson KR and Lamming GE (1996): Regulation of oxytocin, oestradiol and progesterone receptor concentrations in different uterine regions by oestradiol, progesterone and oxytocin in ovariectomised ewes. J. Endocrin. 151, 375-393.

Watson ED, Bjorksten TS, Buckingham $J$ and Nikolakopoulos $E$ (1997): Immunolocalisation of oxytocin in the uterus of the mare. J. Reprod. Fert. Abstract Series 20, 31.

\section{Dr. T.A.E. Stout, (from 1.7.99)}

Department of Equine Studies Faculty of Veterinary Medicine Utrecht University

Utrecht

The Netherlands

Tel: ++31-30-2 531057
Professor W.R. Allen

T.B.A. Equine Fertility Unit Mertoun Paddocks Woodditton Road Newmarket Suffolk CB8 9BH, U.K.

Tel: ++44-1638-662 491 Fax: ++44-1638-667 207 